\title{
An Empirical Investigation of Capital Structure in US Corporate Spinoffs
}

\author{
Tahsina Haque Simu \\ Assistant Professor, Department of Business Administration, Shahjalal University of Science and Technology, \\ Sylhet-3114, Bangladesh
}

\begin{abstract}
This article aims to examine the leverage choice in a corporate spin-off with those of counterparts. The factors that determine the choice of leverage in a spin-off differ from those that influence leverage ratios in firms those were not subject of spin-off. The sample used in this study consists of completed spin-offs announced between 1992 and 2016 in USA. The two competing capital structure theories-trade-off and pecking order are tested for the above-mentioned sample in this study. The results in this article are consistent with the predictions of the tradeoff theory and indicate that firms weigh the costs and benefits of debt when they make capital structure decisions. Empirical studies using year-end debt ratios of firms therefore distort the impact of the factors influencing leverage choice. This study avoids the problem faced by researchers when firms deviate from target leverage ratio by investigating the capital structure of a divested subsidiary in a spin-off.
\end{abstract}

Keywords: Spin-off, capital structure theories

DOI: $10.7176 /$ RJFA/10-13-02

Publication date:July $31^{\text {st }} 2019$

\section{Introduction}

Spin-offs provide a unique setting to examine capital structure choice because one observes the initial capital structure of a mature firm. Prior to this event, the subsidiary is unable to issue equity and relies on the parent to finance its capital investments. The subsidiary therefore has little if any debt and does not manage its capital structure. In a spin-off, the parent divides the assets of the firm and chooses the capital structure for the new, standalone entity. Thus, the choice of leverage for the subsidiary is revealed.

Unlike the firms in other capital structure studies, the subsidiary's leverage ratio is its initial capital structure. The aim of this study is to investigate how firms determine their initial capital structure in a corporate spinoff. This motivation is similar to Alderson and Betker's (1995) and Gilson's (1997) examinations of the role of transaction and liquidation costs in the leverage choice of firms emerging from financial distress. Gilson finds that high transaction costs lead firms to retain more debt. Dittmar (2004) investigated how firms determine the capital structure of a subsidiary that is divested in a spinoff and found results supporting the predictions of the tradeoff theory of capital structure. But this study did not consider debt capacity assumption. Lemmon et al (2010) examined the impact of explicitly incorporating a measure of debt capacity in recent tests of competing theories of capital structure. They concluded that after accounting for debt capacity, the pecking order theory appears to give a good description of financing behavior for a large sample of firms examined over an extended time period. An extension of these two studies would be to compare capital structure theories (pecking order and tradeoff theory) empirically with debt capacity assumption for corporate spinoffs. This will provide valuable insight into which competing theories of capital structure work for corporate spinoffs and why and if these firms try to converge to a target leverage within next few years of divestiture.

\section{Literature Review}

Most of the previous analysis of capital structure examines firms' leverage ratios. Fischer, Heinkel, and Zechner (1989) discuss the problems that result from using leverage ratios to investigate how firms determine their capital structure. They model the impact of the cost to adjust leverage and explain how empirical tests that use year-end debt ratios are biased since observed leverage ratios depend on past operations. Shyam-Sunder and Myers (1999) use simulations to investigate the impact of historical decisions on capital structure and show that the trade-off theory may appear to work because the serial correlation and cyclicality of earnings and capital expenditures induce mean reversion in firms' debt ratios. This mean reversion can be misinterpreted as reversion to a target ratio. If firms choose an optimal leverage ratio, then firm characteristics will determine leverage choice. The relations between firm characteristics and leverage are more easily detectable in the spinoff sample because the leverage ratios do not evolve from prior operating histories but rather are chosen.

The results from Dittmar (2004) study indicate that firms make strategic capital structure decisions and imply that size, growth, and collateral value influence debt choice. However, profitability, which is strongly significant in other studies, does not influence the choice of debt. Thus, the factors that cause the negative relation do not influence the spun off subsidiaries' capital structure decisions. If profits are correlated with growth opportunities that are not captured by other measures of growth, then this negative relation is consistent with the trade-off theory. 
Shyam-Sunder and Myers (1999) also provide evidence that sample firms largely act to fund their financing deficits with debt and conclude that the pecking order theory provides a good first-order approximation of their financing behavior. Consistent with this view, Fama and French (2002) report that short-term variation in earnings and investment is mostly absorbed by debt. In contrast, Frank and Goyal (2003) show that Shyam-Sunder and Myers' empirical findings supporting the pecking order theory do not survive when a broader sample of firms or a longer time series is used, while Chirinko and Singha (2000) argue that the empirical test used by Shyam-Sunder and Myers has little power to distinguish among alternative financing schemes.

Lemmon et al (2010) modified the Shyam-Sunder and Myers (1999) test by accounting for heterogeneity in the level of debt capacity across firms and show that when firms must seek external funding, those most likely to be unconstrained by concerns over debt capacity primarily use debt to fill their financing deficits, while those firms with limited debt capacity exhibit a heavy reliance on external equity financing. Lemmon et al (2010) showed that it is precisely the small, high-growth firms that also face the most restrictive debt capacity constraints. Overall, the evidence suggests that the frequent equity issues by young, high-growth firms are consistent with the existence of debt capacity constraints and do not contradict a version of the pecking order that recognizes limits to the use of debt financing.

Bolton and Freixas (2000), in a model that is very closely related to the theory underlying the pecking order, provide an empirically implementable description of debt capacity. They present a model of financing choice in which the main friction is asymmetric information between the firm and the market. Bolton and Freixas also suggest measures of firm risk or firm age as alternative proxies for debt capacity. Holmstrom and Tirole (1997) also provide a model in which the presence or absence of public or rated debt is related to the firm's level of debt capacity. In their model, a firm's debt capacity is determined by its available collateral. Holmstrom and Tirole point out that a firm's debt capacity may be driven by demand- and/or supply-side considerations. Consistent with a firm's use of public debt as an indication of debt capacity, Whited (1992), Carpenter, Fazzari, and Peterson (1998), Almeida, Campello, and Weisbach (2004), and many others have used the existence of a bond rating as an empirical measure of whether firms face financing constraints in the external financial markets.

\section{Development of Hypothesis}

Historical operating and financial decisions influence these ratios. For instance, a string of unexpectedly high (low) profits will push leverage below (above) the target leverage ratio. If firms continuously adjust their capital structure, they will immediately correct these deviations. However, if transaction costs or market conditions prevent quick movements back to the target, firms will at least temporarily deviate from their target leverage ratio. This temporary deviation may induce a negative relation between leverage and profit. Numerous papers on capital structure document that leverage and profit are negatively correlated. If profits are correlated with growth opportunities that are not captured by other measures of growth, then this negative relation is consistent with the trade-off theory. However, if growth does not induce the negative relation between profits and leverage, then the trade-off theory cannot explain this relation.

Dittmar (2004) found that the average debt to value of the subsidiaries is significantly lower than that of their pre- and post-spin-off parents. The subsidiaries' and the pre and post-spin-off parent's leverage ratios are higher than those of their industry. Thus, the firm chooses a lower leverage ratio for the subsidiary. These results imply that the previously documented negative relation between leverage and profit derives from distortions in firms' leverage ratios that occur over time rather than from a true economic choice. From the above discussion, the hypotheses can be stated as:

H1. Leverage is negatively associated with profitability in corporate spinoffs. (Test of pecking order)

H2. Spinoff firms have an optimal or target capital structure and they lever the firm to coincide with this target. (Test of trade off theory)

\section{Sample Construction}

A spin-off is a pro rata distribution of the stock of a subsidiary to existing shareholders. The subsidiary may be an existing division or a newly created subsidiary of the parent. At the time of the spin-off, the subsidiary becomes a freestanding company. No funds are raised in a spin-off, and neither firm revalues its assets. Under Internal Revenue Code section 355, a spin-off is considered a tax-exempt distribution if after the spin-off the parent retains no more than a $20 \%$ interest in the voting power of all classes of voting stock and no more than a $20 \%$ interest in each class of nonvoting stock. In addition, the distribution may not be executed as a means of distributing dividends to the stockholders, and both corporations must be engaged in active business after the spin-off and for 5 years preceding the spin-off. Due to the strong tax incentive, most spin-offs involve the near-complete divestiture of the subsidiary. Thus, the parent allocates the assets and liabilities to a freestanding company.

The sample used in this study consists of completed spin-offs announced between 1992 and 2016, collected from SDC platinum and then data for these are collected from WRDS database. The accounting data for the firms are collected from Compustat. It is possible for firms to spin off a subsidiary in two stages, where first a portion 
of the subsidiary is carved out and then the rest of the shares are distributed tax-free to shareholders of the parent company. The characteristics of this subsample may differ from the rest of the sample because the subsidiary is publicly traded with access to equity markets before the spin-off and the inflow of cash from the carve-out may alter the capital structure.

\section{Variable Measurement}

The main variables used include the following.

Collateral: the ratio of property, plant, and equipment (PPE) to total assets.

The market-to-book (MB) ratio: Book value/Market value

Profitability (ROA): the ratio of operating profits to total assets.

Firm age and Firm Characteristics Variables

All these are collected from Compustat.

\section{Research Design}

Predicted Leverage ratios:

Debt $/$ Value-E(Debt/Value $)=\alpha+\beta_{1} \ln ($ Assets $)+\beta_{2}($ Growth Opportunities $)+\beta_{3}($ ROA $)+\beta_{4}[($ Inventory + PPE $) /$ Assets $]$

\section{Results}

Descriptives:

\begin{tabular}{|c|c|c|}
\hline Year & Announced Spin-offs (No.) (declared) & Occurred Spin-offs (No.) (effective) \\
\hline 1992 & 22 & 12 \\
\hline 1993 & 26 & 25 \\
\hline 1994 & 30 & 27 \\
\hline 1995 & 49 & 42 \\
\hline 1996 & 38 & 45 \\
\hline 1997 & 43 & 38 \\
\hline 1998 & 46 & 49 \\
\hline 1999 & 36 & 36 \\
\hline 2000 & 43 & 34 \\
\hline 2001 & 17 & 30 \\
\hline 2002 & 19 & 25 \\
\hline 2003 & 26 & 18 \\
\hline 2004 & 16 & 19 \\
\hline 2005 & 15 & 17 \\
\hline 2006 & 14 & 13 \\
\hline 2007 & 27 & 22 \\
\hline 2008 & 18 & 26 \\
\hline 2009 & 9 & 9 \\
\hline 2010 & 10 & 11 \\
\hline 2011 & 22 & 14 \\
\hline 2012 & 18 & 18 \\
\hline 2013 & 33 & 21 \\
\hline 2014 & 37 & 36 \\
\hline 2015 & 19 & 30 \\
\hline 2016 & 5 & 21 \\
\hline
\end{tabular}

Table 1: Spin-off Sample by Year

Table 1 lists the sample by the year in which the spin-off is announced and the year in which the spin-off occurred. Sample observations are dispersed evenly throughout the sample period.

\begin{tabular}{|c|c|c|}
\hline Target Firm Status & Frequency & Percent \\
\hline Joint Venture & 3 & 0.47 \\
\hline Private & 6 & 0.94 \\
\hline Public & 100 & 15.67 \\
\hline Subsidiary & 529 & 82.92 \\
\hline
\end{tabular}

Table 2: Target Status 
The status of the target firm are listed in table 2.

\begin{tabular}{|c|c|}
\hline Range & $\%$ Owned After Transaction \\
\hline $0-10 \%$ & 0.47 \\
\hline$>20 \%$ & 0.95 \\
\hline$>40 \%$ & 2.37 \\
\hline$>60 \%$ & 6.62 \\
\hline$>80 \%$ & 11.04 \\
\hline $100 \%$ & 78.71 \\
\hline
\end{tabular}

Table 3: \% of shares owned after transaction

The proportion of shares owned by parent after a spin-off transaction are listed in table 3 .

\begin{tabular}{|c|c|c|}
\hline & Spinoff year & After spinoff \\
\hline Total Debt/Equity Mean & 8.01 & 6.76 \\
\hline Total Debt/Total Assets Mean & 0.66 & 0.66 \\
\hline Total Debt/Capital Mean & 0.506 & 0.61 \\
\hline Total Debt/Invested Capital Mean & .812 & 0.81 \\
\hline Long-term Debt/Invested Capital Mean & 1.66 & 0.65 \\
\hline Long-term Debt/Book Equity Mean & 1.19 & 1.25 \\
\hline Interest coverage & -0.25 & -.301 \\
\hline Interest coverage ratio & 18.45 & 18.26 \\
\hline
\end{tabular}

Table 4: Leverage ratios in event year and after

\begin{tabular}{|c|c|c|c|c|c|}
\hline & Year 1 & Year 2 & Year 3 & Year 4 & Year 5 \\
\hline Total Debt/Equity & 2.97 & 2.0 & 3.30 & 2.91 & 2.39 \\
\hline Total Debt/Total Assets & 0.62 & 0.63 & 0.62 & 0.62 & 0.60 \\
\hline Total Debt/Capital & 0.46 & 0.47 & 0.53 & 0.53 & 0.37 \\
\hline Total Debt/Invested Capital & 0.55 & 0.50 & 0.57 & 0.31 & 0.48 \\
\hline Long-term Debt/Invested Capital & 0.37 & 0.36 & 0.41 & 0.28 & 0.35 \\
\hline Long-term Debt/Book Equity & 0.99 & 1.08 & 1.11 & $1 . .00$ & 1.11 \\
\hline
\end{tabular}

Table 5: Leverage Ratios for Subsidiaries in subsequent years

Regression Analysis:

\begin{tabular}{|c|c|c|c|c|c|c|c|}
\hline & \multicolumn{7}{|c|}{ Leverage ratios } \\
\hline Ln (Assets)(Size) & $\begin{array}{l}0.03 \\
(.13)\end{array}$ & & & & & $\begin{array}{l}0.02 \\
(.35)\end{array}$ & $\begin{array}{l}.03 \\
(.30)\end{array}$ \\
\hline R\&D/Sales (Growth) & & $\begin{array}{l}-.15 \\
(.02)\end{array}$ & & & & $\begin{array}{l}-.19 \\
(.04)\end{array}$ & $\begin{array}{l}-.17 \\
(.05)\end{array}$ \\
\hline $\mathrm{M} / \mathrm{B}$ ratio & & & $\begin{array}{l}-0.02 \\
(.51)\end{array}$ & & & & $\begin{array}{l}-0.02 \\
(.79)\end{array}$ \\
\hline $\mathrm{ROA}$ & & & & $\begin{array}{l}0.05 \\
(.14)\end{array}$ & & $\begin{array}{l}-0.02 \\
(.83)\end{array}$ & $\begin{array}{l}-0.04 \\
(.45)\end{array}$ \\
\hline Collateral & & & & & $\begin{array}{l}0.29 \\
(.01) \\
\end{array}$ & $\begin{array}{l}0.27 \\
(.03) \\
\end{array}$ & $\begin{array}{l}.17 \\
(.13) \\
\end{array}$ \\
\hline Intercept & $\begin{array}{l}.18 \\
(.01)\end{array}$ & $\begin{array}{l}.26 \\
(.02)\end{array}$ & $\begin{array}{l}.27 \\
(.02)\end{array}$ & $\begin{array}{l}.26 \\
(.02)\end{array}$ & $\begin{array}{l}.26 \\
(.01)\end{array}$ & $\begin{array}{l}.11 \\
(.15)\end{array}$ & $\begin{array}{l}.09 \\
(.25)\end{array}$ \\
\hline No. of observations & 380 & 380 & 373 & 380 & 355 & 345 & 315 \\
\hline
\end{tabular}

Table 6: Spinoff firm's capital structure levels: Leverage ratios

Table 6 presents the results of estimating model using the leverage ratio as the dependent variable. The results show that growth, as measured by the ratio of R\&D to sales, and the collateral value of assets, as measured by the ratio of inventory and PP\&E to assets, significantly influence the choice of debt. A one standard deviation increase in growth results in a $15 \%$ decrease in the book leverage ratio chosen by the subsidiary. A one standard deviation increase in relative collateral value of assets results in an $29 \%$ increase in the book leverage ratio chosen by the subsidiary. Thus, these variables are both statistically and economically significant. The market to book ratio is insignificant. This result is surprising given the significance of $\mathrm{R} \& \mathrm{D} / \mathrm{sales}$ and the results of other studies. The insignificance of the coefficient on market to book may be due to the volatility of the ratio discussed in the previous section or the subsidiaries' market to book ratios may not accurately account for the firms' growth opportunities. Cusatis et al. (1993) and Desai and Jain (1999) show that a portfolio of spun-off subsidiaries significantly outperforms a portfolio of size- and industry-matched firms over the 3 years following the event. Thus, the market 
value shortly after the spin-off may not fully reflect firm value or growth opportunities.

Predicted Leverage ratio: Debt/Value-E(Debt/Value $)=\alpha+\beta_{1} \ln ($ Assets $)+\beta_{2}$ (Growth Opportunities $)+\beta_{3}(\mathrm{ROA})+$ $\beta_{4}[($ Inventory + PPE $) /$ Assets $]$

\begin{tabular}{|c|c|c|c|c|c|c|}
\hline & $(1)$ & $(2)$ & $(3)$ & $(4)$ & $(5)$ & $(6)$ \\
\hline Size (ln Assets) & 0.03 & & & & & \\
& $(.21)$ & & & & & \\
\hline R\&D/Sales & & -.30 & & & & \\
& & $.01)$ & & & & \\
\hline $\mathrm{M} / \mathrm{B}$ ratio & & & -.06 & & & \\
& & & $(.12)$ & & & \\
\hline ROA & & & & .55 & & \\
& & & & $(.01)$ & & \\
\hline Collateral & & & & & .15 & \\
& & & & & $(.81)$ & \\
\hline Intercept & .51 & -0.02 & -0.04 & -.08 & -.08 & -.31 \\
\hline No of Obs & 310 & 310 & 310 & 310 & 310 & 310 \\
\hline R square & .22 & .06 & .02 & .05 & .35 & .37 \\
\hline
\end{tabular}

Table 7: Analysis of Differences in Subsidiaries actual and Predicted leverage ratio

where the time is the year of the spin-off, E indicates the predicted leverage ratio, and value is the book value of assets. Thus, the coefficients represent difference in the subsidiaries' and predicted leverage ratios. The results, presented in table 7, are striking and illustrate the difference in the factors influencing nonsample firms' leverage ratios and the choice of initial leverage in a spin-off. Relative leverage ratios are positively related to profits. This finding contrasts with the results in other studies that show a negative relation between leverage and profit and further indicates that the inverse relation between leverage and profitability occurs only in nonsample firms that have operating histories. The result continues to hold when market to book ratios are used to control for growth opportunities, indicating that the difference in the relation does not stem from the correlation between growth and profit. This result implies that the negative relation between leverage and profits derives from the influence operating histories have on the leverage ratios. The coefficients on all other firm characteristics are insignificant, indicating that their influence on the subsidiaries' leverage ratios is not significantly different than their influence for all firms.

\section{Conclusion}

The subsidiaries are supposed to have lower leverage ratios if they are small with high growth opportunities. However, when the subsidiaries are large and have higher collateral value, they have higher leverage ratios. The leverage ratio chosen for the subsidiaries may be insignificantly different from their predicted leverage ratios. The factors that determine the choice of leverage in a spin-off differ from those that influence nonsample firms' leverage ratios. Growth and collateral value may have significant influence in leverage choice. High growth firms choose lower leverage ratios, and firms with high collateral value choose higher leverage ratios.

The test of competing theories would be interesting to explore in a sample of spinoff firms. If tradeoff theory or pecking order work for the sample firms, but not for the parent firms, then there is important implications for the results.

Despite extensive investigations into how firms determine their capital structures, the capital structure puzzle prevails. One of the difficulties researchers face in these studies is that a firm may deviate from its target leverage ratio. These deviations arise because operating and financial decisions push leverage above or below the firm's target and transaction costs and market conditions may prevent immediate corrections. Empirical studies using year-end debt ratios of firms therefore distort the impact of the factors influencing leverage choice. This study avoids these problems by investigating the capital structure of a divested subsidiary in a spin-off. In a spin-off, the firm allocates assets and chooses a capital structure for the newly formed, stand-alone subsidiary.

Prior to this event, the subsidiary exists but does not have an individual capital structure. Thus, the leverage ratio used in this article is the initial leverage for the firm. Firms make systematic leverage choices and allocate debt based on firm characteristics. These results support the predictions of the trade-off theory. Specifically, growth is negatively related and collateral value is positively related to leverage choice. Further, profitability is not inversely related to leverage choice and is positively related to the difference in a firm's actual and predicted leverage ratio. This finding contrasts with the findings of many other capital structure studies that find a negative relation between profit and nonsample firms' leverage ratios. This negative relation is typically attributed either to growth or to factors that cause a firm to deviate from its target capital structure. Once growth is controlled for, any negative relation that remains between leverage and profits contradicts the trade-off theory. Conversely, the results in this article are consistent with the predictions of the trade-off theory and indicate that firms weigh the costs and 
benefits of debt when they make capital structure decisions. This article focuses on the initial leverage choice in a corporate spin-off and how these leverage ratios compare to nonsample firms.

\section{References}

Alderson, M. J., \& Betker, B. L. (1995). Liquidation costs and capital structure. Journal of Financial Economics, 39(1), 45-69.

Almeida, H., Campello, M., \& Weisbach, M. S. (2011). Corporate financial and investment policies when future financing is not frictionless. Journal of Corporate Finance, 17(3), 675-693.

Bolton, P., \& Freixas, X. (2000). Equity, bonds, and bank debt: Capital structure and financial market equilibrium under asymmetric information. Journal of Political Economy, 108(2), 324-351.

Cusatis, P. J., Miles, J. A., \& Woolridge, J. R. (1993). Restructuring through spinoffs: The stock market evidence. Journal of Financial Economics, 33(3), 293-311.

Carpenter, R. E., Fazzari, S. M., \& Petersen, B. C. (1998). Financing constraints and inventory investment: A comparative study with high-frequency panel data. The Review of Economics and Statistics, 80(4), 513-519.

Chirinko, R. S., \& Singha, A. R. (2000). Testing static tradeoff against pecking order models of capital structure: A critical comment. Journal of Financial Economics, 58(3), 417-425.

Desai, H., \& Jain, P. C. (1999). Firm performance and focus: long-run stock market performance following spinoffs. Journal of financial economics, 54(1), 75-101.

Dittmar, A. (2004). Capital structure in corporate spin-offs. The Journal of Business, 77(1), 9-43.

Fama, E. F., \& French, K. R. (2002). Testing trade-off and pecking order predictions about dividends and debt. The Review of Financial Studies, 15(1), 1-33.

Fischer, E. O., Heinkel, R., \& Zechner, J. (1989). Dynamic capital structure choice: Theory and tests. The Journal of Finance, 44(1), 19-40.

Flannery, M. J., \& Rangan, K. P. (2006). Partial adjustment toward target capital structures. Journal of financial economics, 79(3), 469-506.

Frank, M. Z., \& Goyal, V. K. (2003). Testing the pecking order theory of capital structure. Journal of Financial Economics, 67(2), 217-248.

Gilson, S. C. (1997). Transactions costs and capital structure choice: Evidence from financially distressed firms. The Journal of Finance, 52(1), 161-196.

Holmstrom, B., \& Tirole, J. (1997). Financial intermediation, loanable funds, and the real sector. The Quarterly Journal of Economics, 112(3), 663-691.

Lemmon, M. L., \& Zender, J. F. (2010). Debt capacity and tests of capital structure theories. Journal of Financial and Quantitative Analysis, 45(5), 1161-1187.

Shyam-Sunder, L., \& Myers, S. C. (1999). Testing static tradeoff against pecking order models of capital structure. Journal of Financial Economics, 51(2), 219-244.

Whited, T. M. (1992). Debt, liquidity constraints, and corporate investment: Evidence from panel data. The Journal of Finance, 47(4), 1425-1460. 